\title{
The Effect of Context on Learning Idioms By Iranian EFL Learners
}

\author{
${ }^{\mathrm{a}}$ Fahimeh Raeisi Souzaei, ${ }^{\mathrm{b}}$ Ali Akbar Jabbari \\ ${ }^{a}$ MA student of English Language Teaching Islamic Azad University, Bandar Abbas Branch, Iran \\ ${ }^{b}$ Associate professor of applied linguistics, Yazd University, Iran
}

\begin{abstract}
The purpose of the present study was the investigation of the effect of context on teaching Idioms and using contextual-clues by the EFL learners for getting the meaning of Idioms. For this aim, 60 out of 80 students were selected through administration of Nelson English Language Test and were randomly assigned to control and experimental groups. Both groups took part in the per-test. In each session, the same Idioms from the Idioms organizer book were presented to the participants in both groups and some exercises from the book were done to make them more characterize to students. The contextualization of the Idioms was administered and its results were compared with the results of per-test through a paired samples t-test. The results revealed that there was a significant difference in learning the meaning of Idioms by using them in favor of the former. The findings have significant pedagogical implication for Iranian EFL learners, teachers, course book designer and material developers in providing a better context for Learning English.
\end{abstract}

Key words: Idiom, Figurative language, Metaphor, Literal meaning, Simile

\section{INTRODUCTION}

Lewis claimed that language, as a social phenomenon, is composed of words and multi-word units or multi-word (lexical) items such as idioms (Beloussova, 2015). According to Lennon (1998), idioms are considered as the colorful side of language; they are a set of language symbols used in communicating thoughts and feelings. They make language full of life and richness by taking the existing words, combining them in a new sense, and creating new meanings, just like a work of art. Language is more or less idiomatic and there is no scale of idiomacity. It is not the case that idioms can be thrown in from time to time to spice the linguistic dish. Prodromou (2003) believed that idiomacity is a necessity and the reason is that it makes language more real. According to Fernando, knowledge of idioms will help students to be better speakers and negotiators. The sheer number of idioms and their high frequency in discourse make them an important aspect of vocabulary acquisition and language learning in general. (Cooper, 1998)

Unlike novel phrases, idioms are called as integral units. Most native speakers frequently use idioms in their daily lives; consequently, idioms form a very important part of any natural language (Bulut \& Yazici, 2004). The general tendencies of the present day English are towards more idiomatic usage; it is important that the learners accept idioms as a part of language which one cannot choose either to use or to omit, but they form an essential part of the general vocabulary of English. (Seidle \& McMordic, 1984)

\section{METHODOLOGY}

Participants

The sample of the present study was drawn from among 80 students learning English language at Noor Institute in Qeshm including 34 males and 46 females at the intermediate level taken from two intact classes at the institute. For the purpose of homogeneity, prior to research a Nelson English Language Test, as a proficiency test, was given to the initial 80 students and 60 students - 27 males and 33 females - whose scores were between one standard deviation below and above the mean took part in the study. These then were randomly assigned to control and experimental groups. All participants were in the age range of 18 to 22 .

\section{DESIGN OF THE STUDY}

The present study included pre-test, post-test, control group and experimental group. Therefore, the design of the study was 'pre-test, post-test, control group' (Hatch \& Lazaraton, 1991). 
This study was also a quasi-experimental research as the participants were not randomly selected out of the whole population considered for the study. In this study the idiom teaching methodology was the independent variable (with two levels of explicit instruction and use of context) which its effect on the learning of the meaning of idioms as the dependent variable was investigated.

\section{INSTRUMENTS}

In order to conduct the present study, following instruments were used:

1.Nelson English Language Test: was used as a tool for homogenizing participants of the study. The Nelson English Language Test is a battery including 40 separate tests for ten levels of language proficiency which range from beginner to the advanced. The levels are numbered from 050, 100, $\ldots$, to 500 . Each test consists of 50 items. In the present study a test in intermediate level $-250 \mathrm{~A}-$ was used.

2.Pre- and Post-test: a researcher-made test of the idioms was used as to check the idiom knowledge of the participants before and after the study. This test consisted of 30 items that each one was attempting to set the scene to use a specific idiom. The answers to the questions were in a multiplechoice format with four choices printed below each question. The students were supposed to determine the meaning of each idiom in choices and consequently select the best choice. Only idiomatic meaning of the idiom string was plausible as the correct answer. The reliability of this test was checked through KR-21 formula and indicated the index of 0.81. In addition, the validity of the test was confirmed by three experienced teachers of English.

\section{DATA ANALYSIS}

Data analysis was done by SPSS 17 software. A number of descriptive and inferential analyses were conducted on the data. The data was analyzed descriptively using mean and standard deviation. An independent samples t-test was used to compare the performance of both experimental and control groups before the treatment period in the pre-test. The first null hypothesis of the study was explored through running a paired samples t-test. The second null hypothesis was investigated by an independent samples t-test.

\section{RESULTS}

This chapter presents the results of the data analyses with illustrative tables. The chapter begins by reporting the results of Nelson English Language Test. Then, it displays the descriptive statistics for the pre- and post-tests test in both control and experimental groups. Finally the results of the paired samples t-test and independent samples t-test comparing the performance of the two groups in the tests are presented.

\section{HOMOGENIZING THE PARTICIPANTS}

As it was mentioned in Chapter Three, a Nelson English Language Test was used to homogenize the participants of the study. To select the participants, all initial 80 students took part in Nelson English Language Test and students whose score was between one standard deviation below and above the mean participated in the main study. Table 4.1 shows the descriptive statistics of the participants' Nelson scores.

Table 1.Descriptive Statistics of the Participants' Nelson English Language Test Scores

\begin{tabular}{|l|c|c|c|c|c|}
\hline & $\mathrm{N}$ & Minimum & Maximum & Mean & Std. Deviation \\
\hline Nelson & 46 & 20 & 50 & 33.07 & 8.481 \\
\hline Valid N (listwise) & 46 & & & & \\
\hline
\end{tabular}

As the table shows, mean and standard deviation of the initial participants' Nelson English Language Test scores were 33.07 and 8.481, respectively. From these initial participants, 32 students whose score were between 25 and 41 were chosen.

\section{NORMALITY CHECK}

The normal distribution of the data is a prerequisite condition for running parametric statistical analyses. In order to make sure about the normal distribution of the scores in both control and experimental groups, the researcher performed a One-Sample Kolmogorov-Smirnov Test on four sets of scores. Table 4.4 presents the results of this analysis. 
Table 2.Normality Check of Pre-Test and Post-Test Scores in Control and Experimental Groups

\begin{tabular}{|c|c|c|c|c|c|}
\hline & & $\begin{array}{c}\text { Pre-Test of } \\
\text { Control } \\
\text { Group }\end{array}$ & $\begin{array}{l}\text { Pre-Test } \\
\text { of } \\
\text { Experime } \\
\text { ntal } \\
\text { Group }\end{array}$ & $\begin{array}{l}\text { Post-Test } \\
\text { of } \\
\text { Control } \\
\text { Group }\end{array}$ & $\begin{array}{c}\text { Post-Test } \\
\text { of } \\
\text { Experime } \\
\text { ntal } \\
\text { Group }\end{array}$ \\
\hline \multicolumn{2}{|l|}{$\mathrm{N}$} & 16 & 16 & 16 & 16 \\
\hline \multirow[t]{2}{*}{ Normal Parameters ${ }^{\mathrm{a}, \mathrm{b}}$} & Mean & 19.94 & 19.81 & 22.44 & 25.13 \\
\hline & $\begin{array}{l}\text { Std. } \\
\text { Deviation }\end{array}$ & 2.568 & 2.257 & 2.337 & 2.604 \\
\hline \multirow{3}{*}{$\begin{array}{l}\text { Most Extreme } \\
\text { Differences }\end{array}$} & Absolute & .164 & .221 & .227 & .167 \\
\hline & Positive & .150 & .217 & .227 & .167 \\
\hline & Negative & -.164 & -.221 & -.148 & -.132 \\
\hline \multicolumn{2}{|l|}{ Kolmogorov-Smirnov Z } & .164 & .221 & .227 & .167 \\
\hline \multicolumn{2}{|c|}{ Asymp. Sig. (2-tailed) } & .200 & .136 & .128 & .200 \\
\hline \multicolumn{6}{|c|}{ a. Test distribution is Normal. } \\
\hline \multicolumn{6}{|c|}{ b. Calculated from data. } \\
\hline
\end{tabular}

As it is indicated in Table 4.4, p-value for both sets of scores is higher than 0.05 , therefore all sets of scores have normal distributions and the parametric tests of paired samples and independent samples $t$-test can be run.

\section{The Results Regarding the First Research Hypothesis}

In order to determine the effect that teaching idioms in context may have on the learning of idioms by EFL learners, the researcher performed a paired samples t-test. Table 4.5 presents the results of this analysis.

Table 3.Paired Samples T-test of Pre- and Post-Test Scores in the Experimental Group

\begin{tabular}{|c|c|c|c|c|c|c|c|c|}
\hline & \multicolumn{5}{|c|}{ Paired Differences } & \multirow[t]{3}{*}{$\mathrm{t}$} & \multirow{3}{*}{$\begin{array}{l}\mathrm{d} \\
\mathrm{f}\end{array}$} & \multirow{3}{*}{$\begin{array}{l}\text { Sig. } \\
(2- \\
\text { tailed } \\
\quad)\end{array}$} \\
\hline & \multirow[t]{2}{*}{$\begin{array}{c}\text { Mea } \\
\mathrm{n}\end{array}$} & \multirow{2}{*}{$\begin{array}{l}\text { Std. } \\
\text { Deviat } \\
\text { ion }\end{array}$} & \multirow{2}{*}{$\begin{array}{c}\text { Std. } \\
\text { Error } \\
\text { Mean } \\
\end{array}$} & \multicolumn{2}{|c|}{$\begin{array}{l}\text { 95\% Confidence Interval of the } \\
\text { Difference }\end{array}$} & & & \\
\hline & & & & Lower & Upper & & & \\
\hline $\begin{array}{l}\text { Pre-test - Post- } \\
\text { test }\end{array}$ & $\begin{array}{c}- \\
5.31 \\
3\end{array}$ & 1.621 & .405 & -6.177 & -4.448 & $\begin{array}{c}- \\
13.1 \\
05\end{array}$ & $\begin{array}{l}1 \\
5\end{array}$ & .000 \\
\hline
\end{tabular}

As indicated in Table 4.5, there was a significant difference between the pre-test and posttest scores of the participants in the experimental group $(\mathrm{t}(15)=-13.105, \mathrm{p}<0.05)$. According to the means of the two tests shown in Table 4.3, it can be concluded that there was a statistically significant improvement in post-test scores following the learning of idioms by EFL learners.

\section{The Results Regarding the Second Research Hypothesis}

In order to explore whether there was any significant difference between the post-test scores of the participants in control and experimental groups, the researcher ran an independent samples $t$ test. Table 4.6 reports the results of this analysis.

\begin{tabular}{|c|c|c|c|c|c|c|c|c|c|c|}
\hline & & \multicolumn{2}{|c|}{$\begin{array}{l}\text { Levene's Test } \\
\text { for Equality of } \\
\text { Variances }\end{array}$} & \multicolumn{7}{|c|}{ t-test for Equality of Means } \\
\hline & & \multirow[b]{2}{*}{ F } & \multirow[b]{2}{*}{ Sig } & \multirow[b]{2}{*}{$\mathrm{T}$} & \multirow[b]{2}{*}{ df } & \multirow[b]{2}{*}{$\begin{array}{l}\text { Sig. } \\
(2- \\
\text { tailed) }\end{array}$} & \multirow[b]{2}{*}{$\begin{array}{c}\text { Mean } \\
\text { Differe } \\
\text { nce }\end{array}$} & \multirow[b]{2}{*}{$\begin{array}{c}\text { Std. } \\
\text { Enror } \\
\text { Differ } \\
\text { ence }\end{array}$} & \multicolumn{2}{|c|}{$\begin{array}{c}95 \% \\
\text { Confidence } \\
\text { Interval of } \\
\text { the } \\
\text { Difference }\end{array}$} \\
\hline & & & & & & & & & $\begin{array}{l}\text { Lo } \\
\text { wer }\end{array}$ & $\begin{array}{c}\text { Uppe } \\
\text { r }\end{array}$ \\
\hline \multirow[t]{2}{*}{$\begin{array}{l}\text { Post- } \\
\text { test }\end{array}$} & $\begin{array}{l}\text { Equal } \\
\text { variances } \\
\text { assumed }\end{array}$ & .088 & $\begin{array}{c}.76 \\
8\end{array}$ & $\begin{array}{c}-\overline{-} \\
3.07 \\
2\end{array}$ & 30 & .004 & -2.688 & .875 & $\begin{array}{c}- \\
4.4 \\
74\end{array}$ & -.901 \\
\hline & $\begin{array}{l}\text { Equal } \\
\text { variances } \\
\text { not } \\
\text { assumed }\end{array}$ & & & $\begin{array}{c}- \\
3.07 \\
2\end{array}$ & $\begin{array}{c}29.6 \\
55\end{array}$ & .005 & -2.688 & .875 & $\begin{array}{l}- \\
4.4 \\
75\end{array}$ & -900 \\
\hline
\end{tabular}


Based on the results reported in Table 4.6, the Levene's Test for equal variances yields a p-value of 0.768. This means that the difference between the variances is statistically insignificant and the statistics in the first row should be used. The p-value in the first row of the table is equal to .004 which is less than 0.05 and indicates that there is a significant difference between post-test scores of the participants in the control and experimental groups. The $95 \%$ confidence interval for the difference between two means is $(-4.474,-0.901)$.

\section{DISCUSSION}

Results of the pre- and post-test revealed that there was a significant difference in learning the meaning of idioms by using context clues and without using them. To put it another way, it can be argued that learners' awareness of context clues would contribute to their comprehension and learning of unknown idioms to a large and remarkable extent.

The results of this study, thus, support the concept that context has a significant effect on learning L2/FL idiomatic expressions. The findings of this study confirm the results of Liontas (2003) in that the existence of the context significantly affects the comprehension and understanding of the functions of the idioms. He believed that the lack of context puts an essential restriction on comprehending idioms. Kainulainen (2006) also revealed the role of context in understanding idiomatic expressions.

The results of this experiment lead us to conclude that the account we have offered is reasonable. In the normal course of events nonliteral uses of language, be they metaphors, idioms, or indirect speech acts, are comprehended without any special processing. The primarily top-down strategy that is employed in language comprehension enables them to be comprehended in terms of the preceding context quite naturally.

Ortony, Schallert, Reynold, and Antos (1978) proposed that "processing the context activates adequate appropriate schemata to enable an idiomatic expression to be arrived at quite readily" (p. 474). Instructing students to guess the function of idioms from context and to handle figurative speech makes them capable of generalizing beyond those idioms which they have learned and to understand and learn the function of idioms which they have never seen before (Adkins, 1968).

In the limited-context circumstance, the process is somehow different. Doubtlessly, fewer appropriate schemata can be activated (Ortony et al., 1978). A sentence is not sufficient for the understanding the function of the idiomatic expressions. When the idiomatic expression is met in a context, learners use "an already constructed representation of what has gone before (the context) as a conceptual framework for interpreting a target sentence, or any other linguistic unit" (Ortony et al., 1978 , p. 467), therefore it helps in learning idiomatic expressions. In single sentences, however, the target idioms are presented with minimal preceding context. Without adequate contextual support, the learners' ability to activate the schemata reduces but is more than when they encounter idioms out of the context.

\subsection{Conclusions}

This study was carried out in order to identify the role of linguistic context in teaching idioms to Iranian English language learners. In order to investigate the influence of contextual clues in learning idioms, 60 learners were selected by administering the Nelson English Language Test. These learners were then divided into two groups, the control and the experimental groups. Each group consisted of 30 learners. The participants were studying English in Noor Language Institute in Qeshm and their ages ranged from 18 to 22. After calculating and analyzing the data elicited by the achievement test, it was found that the experimental group who used the contextual clues for understanding the meaning of unknown idioms outperformed the control group.

The results concurred with the previous findings (e.g., Ackerman, 1982; Cooper, 1999; Levorato, Nesi, \& Cacciari, 2004) in the sense that Iranian English language learners like other EFL learners can use inference from context procedure for understanding the meaning of unknown or unfamiliar idiomatic expressions, when encounter them in various contexts. Cooper (1999) argues that contextual clues are useful to learners in comprehending unknown idioms. He explored the comprehension strategies used by L2 learners when trying to decipher the meaning of English idioms in one- or two-sentence contexts. He found that the most commonly used strategies were guessing from context, discussing and analyzing the idioms and using the literal meaning. Overall, guessing from context was the most successful strategy, leading to correct interpretation in $57 \%$ of the cases.

Ackerman (1982) in his study examined children's and college adults' comprehension of idioms. Children and adults were asked to read short stories containing contextual information and key terminal sentences. The contextual information biased either an idiomatic (literal) or an ambiguous (neutral) interpretation of the terminal sentence. The terminal sentence contained either 
an idiom (e.g., 'fix his wagon') or a changed from (e.g., 'repair his wagon) of the idiom. These manipulations were used to determine the role of contextual information and the conventional forms of idioms in idiom comprehension. The results of this study showed that context help children and adults in guessing the meaning of idioms.

Because the idioms constitute a special language learning problem for NNSs, idiomatic expressions may deserve special attention in classroom instruction. Offering learners a method for comprehending the unfamiliar idioms is an effective way to approach the task of English idiom acquisition. This study offers learners and instructors how to use context clues to guess the meanings of unknown or unfamiliar idiomatic expressions.

\section{SUGGESTIONS FOR FURTHER RESEARCH}

The purpose of this research was the investigation of the role of context in teaching idioms to Iranian EFL learners. However, studies about the effect of different factors in processing and comprehending idioms, such as relationships concerning different social practices, languages typologically similar/dissimilar, monolingual, multilingual speakers are different areas which need to be explored.

\section{REFERENCES}

[1] Ackerman, B. P. (1982). On comprehending idioms: Do children get the picture? Journal of Experimental Child Psychology, 33, 439-454.

[2] Adkins, P. G. (1968). Teaching idioms and figures of speech to non-native speakers of English. The Modern Language Journal, 52, 148-152.

[3] Beloussova, V. (2015). Idiom learning materials for Estonian secondary school students. (MA Thesis). Retrieved from http://dspace.ut.ee/bitstream/handle/10062/47069/Violetta_Beloussova_MA_thesis1 1.pdf?sequence $=1$

[4] Bulut, T.,Cooper, T. C. (1998). Teaching idioms. Foreign Language Annals, 31, 255-266.

[5] Cooper, T. C. (1999). Processing of idioms by L2 learners of English. TESOL Quarterly, 33, $233-262$.

[6] Yazici, I. C. (2004). Idiom processing in L2: Through rose-colored glasses. Retrieved February 12, 2014 from http://www.readingmatrix.com/articles/bulut_yazici/article.pdf.

[7] Hatch, E., \& Lazaraton, A. (1991). The research manual: Design and statistics for applied linguistics. Boston: Heinle and Heinle.

[8] Irujo, S. (1986a). A piece of cake: Learning and teaching idioms. ELT Journal, 40, 236-242.

[9] Irujo, S. (1986b). Don't put your leg in your mouth: Transfer in the acquisition of idioms in a second language. TESOL Quarterly, 20, 287-304.

[10] Kainulainen, T. (2006). Understanding idioms: A comparison of Finnish third grade students of national senior secondary school and IB diploma programme (master's thesis). Department of Language, University of Jyväskylä.

[11] Lennon, P. (1998). Approaches to the teaching of idiomatic language. IRAL, 36, 11-30.

[12] Levorato, M. C., Nesi, B., \& Cacciari, C. (2004). Reading comprehension and understanding idioms: A development study. Brain and Language, 91, 303-314.

[13] Liontas, J. I. (2003). Killing two birds with one stone: Understanding Spanish VP idioms in and out of context. Hispania, 86(2), 289-301.

[14] Ortony, A., Schallert, D. L., Reynold, R. E., \&Antos, S. J. (1978). Interpreting metaphors and idioms: Some effects of context on comprehension. Journal of Verbal Learning and Verbal Behavior, 17, 465477.

[15] Prodromou, L. (2003). Idiomaticity and the non-native speaker. Retrieved March 29, 2014 from http://journals.cambridge.org/action/displayAbstract.

[16] Seidle, J., \& McMerdic, W. (1984). English idioms and how to use them. Oxford: Oxford University Press. 